\title{
Association between Vitamin D Status and Cardio-Metabolic Risk Factors among Adults with and without Coronary Heart Disease in Saudi Arabia
} Najlaa M Aljefree ${ }^{1,2 *}$, Patricia Lee ${ }^{1,2}$, Jamal M Al Saqqaf ${ }^{3}$ and Faruk Ahmed ${ }^{1,2}$

${ }^{1}$ Public Health, School of Medicine, Griffith University, Gold Coast Campus, Australia

${ }^{2}$ Menzies Health Institute Queensland, Australia

${ }^{3}$ Department of Cardiology, King Abdulla Medical City (KAMC), Makkah, Saudi Arabia

\begin{abstract}
Objective: Recent literature has suggested an association between low serum vitamin $D$ levels and the burden of cardio-metabolic risk factors (obesity, diabetes, hypertension, and hypercholesterolemia). In the context of the high prevalence of vitamin D deficiency and cardio-metabolic risk factors in Saudi Arabia, this study was designed to examine the association between vitamin $\mathrm{D}$ deficiency and cardio-metabolic risk factors among adults with coronary heart disease (CHD) and without CHD in Saudi Arabia.
\end{abstract}

Methods: A total of $130 \mathrm{CHD}$ subjects and 195 subjects without $\mathrm{CHD}$ were recruited from three hospitals in the western region of the Kingdom. Fasting blood samples were collected from each subject to measure serum levels of vitamin D, glucose, and total cholesterol. Anthropometric and blood pressure were also measured

Results: Subjects with CHD had a higher prevalence of diabetes (35.4\% and $14 \%$, respectively) and obesity (44\% and $22 \%$, respectively) compared with subjects without CHD. However, subjects without CHD had a higher prevalence of cholesterol ( $13.3 \%$ and $5.4 \%$, respectively) and overweight ( $45 \%$ and $24.4 \%$, respectively) than subjects with CHD. The results indicated that vitamin $D$ deficiency [serum $25(\mathrm{OH}) \mathrm{D}<20 \mathrm{ng} / \mathrm{mL}$ ] was associated with increased risk of diabetes in CHD subjects (OR: $2.9,95 \% \mathrm{Cl}: 1.02-8.5, p=0.04$ ), while there was no association observed in subjects without $\mathrm{CHD}$ (OR:1.4, 95\% Cl: $0.5-3.8, p=0.616)$. No significant associations were found between vitamin $\mathrm{D}$ deficiency and other cardio-metabolic risk factors including obesity, hypertension, and hypercholesterolemia, in either group.

Conclusion: The present study reveals that vitamin $D$ deficiency was associated with a higher risk of diabetes only in subjects with CHD, but not in subjects without CHD. However, this differential association between vitamin $\mathrm{D}$ deficiency and other cardio-metabolic risk factors was not observed. Further studies are needed to confirm these findings.

Keywords: Vitamin D deficiency; Coronary heart disease; Diabetes; Obesity; Saudi Arabia;Hypertension; MiddleEast; Hypercholesterolemia

\section{Introduction}

Vitamin D deficiency or insufficiency is widespread across the globe and it is currently recognized as a re-emerging public health problem [1]. International research has indicated that the prevalence of vitamin D deficiency ranges from $25 \%$ to $50 \%$ of the total adults in the United States [2]. Similar prevalence rates have also been reported in Europe $[3,4]$. However, the highest rates of vitamin D deficiency have been reported in sunny regions such as Asia and the Middle East [5].

Although vitamin D has widely been known for its significant role in bone health, inadequate levels of vitamin $\mathrm{D}$ have recently been linked to chronic diseases such as cardiovascular disease [6]. In addition, a number of studies have also shown an association between low levels of serum vitamin $\mathrm{D}$ and an increased risk of cardio-metabolic risk factors such as diabetes and obesity [6-9]. Both clinical and animal studies have indicated the role of vitamin $\mathrm{D}$ in regulating cardiac metabolism and reducing the risk of other cardio-metabolic risk factors such as hypertension and high blood lipids [10]. These studies have also suggested some possible mechanisms including the significant role of vitamin $\mathrm{D}$ in regulating the parathyroid hormone and the reninangiotensin-aldosterone system, which in turn changes the blood pressure by reabsorption of water and sodium, hence raising the blood pressure $[10,11]$.

In the Gulf region and Saudi Arabia in particular, the prevalence of cardio-metabolic risk factors has been increasing, mostly because of changing lifestyle along with socio-economic transformations [12]. Several studies among Saudi adults have shown high rates of cardio-metabolic risk factors including obesity (35.6\%), hypertension (26.1\%), diabetes (23.7\%), and hypercholesterolemia (50\%) [13-17]. Furthermore, according to the International Diabetes Federation (IDF), Saudi Arabia is one of the countries with the highest number of estimated diabetic subjects in the world [18]. In addition, a high prevalence of coronary heart disease (CHD) has been reported in the Saudi population (5.5\%) [19]. Data from hospitals in Saudi Arabia have also showed that CHD is the third leading cause of hospital-based death in the kingdom [20]. Figure 1 reflects the hypothesized relationships among study variables. Recently, we have demonstrated an association between vitamin D deficiency and CHD among Saudi adults [21].

*Corresponding author: Najlaa Aljefree, Public Health, School of Medicine and Menzies Health Institute Queensland, Building GO1, Room 3.30, Griffith University Gold Coast Campus, QLD 4222, Australia, Tel: (61-7) 567 27708; Fax: (61-7) 555 28799; E-mail: najlaa.aljefree@griffithuni.edu.au

Received August 10, 2016; Accepted October 15, 2016; Published October 23 2016

Citation: Aljefree NM, Lee P, Saqqaf JMA, Ahmed F (2016) Association between Vitamin D Status and Cardio-Metabolic Risk Factors among Adults with and without Coronary Heart Disease in Saudi Arabia. J Diabetes Metab 7: 707. doi: 10.4172/2155-6156.1000707

Copyright: (c) 2016 Aljefree NM, et al. This is an open-access article distributed under the terms of the Creative Commons Attribution License, which permits unrestricted use, distribution, and reproduction in any medium, provided the original author and source are credited. 
Figure 1: Associations between study variables.

Cardio-metabolic risk factors (obesity, diabetes, hypertension, and hypercholesterolemia)

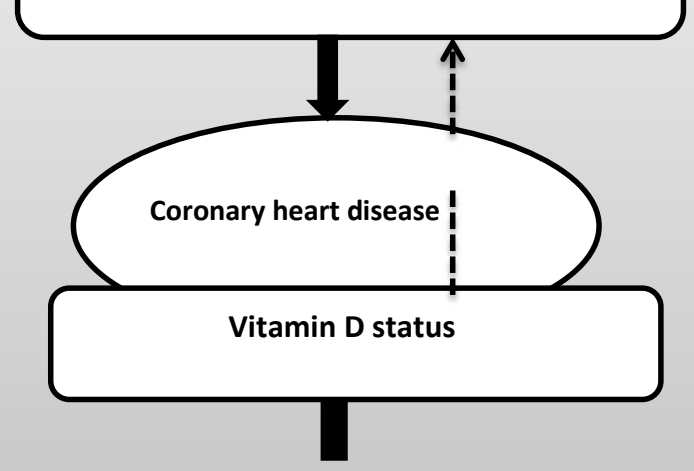

Since various cardio-metabolic risk factors are the major drivers for the development of CHD, it is important to explore whether each of the common cardio-metabolic risk factors is independently associated with vitamin D status in the Saudi population.

Despite genetic predisposition and other factors, such as urbanization and changing lifestyle, that can influence the high prevalence of cardio-metabolic risk factors in Saudi Arabia, evidence has shown that changes in dietary patterns and deficiencies in micronutrients such as vitamin $\mathrm{D}$ might also be contributing to this phenomenon [22,23]. However, there are limited studies in Saudi Arabia that have examined the association between vitamin D status and cardio-metabolic risk factors including diabetes and obesity among healthy adults $[24,25]$. Considering the growing epidemic of cardiometabolic risk factors as well as vitamin D deficiency among the Saudi population, there is a need for further studies to evaluate the association between vitamin $\mathrm{D}$ status as a potential modifiable risk factor and the cardio-metabolic risks in order to develop an appropriate intervention for targeting risk factors that are associated with CHD. Moreover, vitamin $\mathrm{D}$ function may differ between subjects with CHD and subjects without $\mathrm{CHD}$. No previous studies have examined whether the association of vitamin $\mathrm{D}$ deficiency with cardio-metabolic risk factors vary between subjects with $\mathrm{CHD}$ and subjects without $\mathrm{CHD}$. Therefore, this study attempts to evaluate the association between vitamin $\mathrm{D}$ status and cardio-metabolic risk factors including obesity, diabetes, hypertension and hypercholesterolemia among subjects with CHD and subjects without CHD in Saudi Arabia.

\section{Methods}

\section{Study population}

Data collection took place between May and October 2015 during summertime in the two large cities in the western region of Saudi Arabia, Jeddah, and Makkah. The study participants included were adults from both genders. A total of $130 \mathrm{CHD}$ patients were recruited from the cardiology department in King Abdullah Medical City (KAMC) in Makkah and 153 subjects with no CHD were recruited from family medicine clinics and nose and throat (ENT) clinics in Tunsi private hospital in Makkah. An additional 42 subjects with no CHD were recruited from ophthalmology clinics in King Abdul Aziz University (KAU) hospital in Jeddah. Ethical approval has been sought from Griffith University Human Research Ethics Committee (GU Ref No: MED/59/14/HREC), the Institutional Review Board in KAMC (IRB No: 15-194), and the Research Ethics Committee in KAU (Reference No ll8-15). All included subjects were Saudis or residents in KSA for at least five years. Subjects with medical conditions that may potentially affect vitamin D metabolism such as osteoporosis, liver disease, kidney disease, hyperthyroidism and hyperparathyroidism were excluded.

\section{Data collection}

An interviewer-administered questionnaire was used for collecting data after written informed consent was obtained from all participants. Sociodemographic factors such as age, gender, nationality, marital status, level of education, and family income levels were collected. Furthermore, data regarding the family history of cardiovascular disease (CVD) and behavioral risk factors were also collected. Behavioral risk factors collected in the survey included cigarette smoking, water-pipe smoking, and levels of physical activity. A current smoker was defined as a subject who was smoking at least one cigarette per day on a regular basis [26]. A non-smoker was defined as a subject who had never smoked. A person who had previously smoked but had quit was considered a previous smoker [26]. A person who smoked from a water-pipe at least once per week at the time of the interview was considered a water-pipe smoker [27]. Physical activity was classified into the following: moderate activity (such as jogging, walking or swimming), vigorous activity (such as heavy lifting, aerobics or fast bicycling), and sedentary (such as staying at home most of the time or doing a little walking outside) [26]. Information related to the use of vitamin D dietary supplements and calcium supplements with vitamin $\mathrm{D}$ were also collected, including both dosage and duration. Likewise, information on sun exposure and time spent outdoors during weekdays and weekends as well as the use of sunscreen were also collected. Blood pressure, height (meters), and weight (kilograms) were measured after interviewing the study subjects using the hospital's standard equipment. Body mass index (BMI) was calculated as weight (kilograms) divided by height (meters) squared. Obesity was defined as when participants' BMI was $\geq 30 \mathrm{~kg} / \mathrm{m}^{2}$, and a patient was considered overweight when his/her BMI was $25-29.9 \mathrm{~kg} / \mathrm{m}^{2}$ [28]. Hypertension was defined as $\mathrm{BP} \geq 140 \mathrm{mmHg}$ for systolic blood pressure (SBP) and/ or $\geq 90 \mathrm{mmHg}$ for diastolic blood pressure (DBP) [28].

\section{Biochemical measurements}

To measure serum levels of $25(\mathrm{OH}) \mathrm{D}$, total cholesterol and glucose, $10 \mathrm{~mL}$ fasting blood samples were taken from all participants via venipuncture. The serum samples were centrifuged at $2000 \mathrm{rpm}$ for 15 minutes before separation occurred. After that, the blood samples were kept frozen at $-80^{\circ} \mathrm{C}$ for additional lab analyses. The chemiluminescence microparticle immunoassay (CMIA) on the Architect system (Abbott) was used to measure serum levels of $25(\mathrm{OH}) \mathrm{D}$, whereas cholesterol and glucose levels were measured using Thermo Fisher Scientific (Espoo, Finland). Vitamin D deficiency was defined as having a serum level of $25(\mathrm{OH}) \mathrm{D}$ less than $10 \mathrm{ng} / \mathrm{mL}$, insufficient vitamin D level as $25(\mathrm{OH})$ $\mathrm{D} 10$ to $<19.9 \mathrm{ng} / \mathrm{mL}$, and an adequate vitamin $\mathrm{D}$ level was defined as having serum of $25(\mathrm{OH}) \mathrm{D} \geq 20 \mathrm{ng} / \mathrm{mL}$ [29]. Due to the small sample size we combined vitamin $\mathrm{D}$ deficiency and insufficiency for analysis purposes; thus vitamin D deficiency was defined in the current study as having serum of $25(\mathrm{OH}) \mathrm{D}<20 \mathrm{ng} / \mathrm{mL}$. High total cholesterol $(\mathrm{HC})$ was defined according to the Adult Treatment Panel III (ATP III) as HC $\geq$ $240 \mathrm{mg} / \mathrm{dL}$ [28]. Diabetes was defined according to the World Health Organization (WHO) definition as fasting plasma glucose (FPG) at $\geq$ $126 \mathrm{mg} / \mathrm{dL}$ [28]. 
Citation: Aljefree NM, Lee P, Saqqaf JMA, Ahmed F (2016) Association between Vitamin D Status and Cardio-Metabolic Risk Factors among Adults with and without Coronary Heart Disease in Saudi Arabia. J Diabetes Metab 7: 707. doi: 10.4172/2155-6156.1000707

Page 3 of 7

\section{Statistical analysis}

Statistical Package for Social Science (SPSS) version 22 was used to perform the statistical analyses. A series of chi-square tests were used to compare the sociodemographic, family history of CVD, and lifestyle behavior variables for both groups according to vitamin D status [deficient as serum $25(\mathrm{OH}) \mathrm{D}<20 \mathrm{ng} / \mathrm{mL}$, and adequate as serum $25(\mathrm{OH}) \mathrm{D} \geq 20 \mathrm{ng} / \mathrm{mL}$ ]. Also, dependent variables (obesity, diabetes, total cholesterol, and hypertension) were tested for all sociodemographic and lifestyle characteristics using chi-square tests or Fisher's exact tests as appropriate to identify the possible confounders (data not showed). Results were reported as \% (N) for categorical variables.

Multivariate logistic regression models were conducted to examine the associations between vitamin D status and cardiometabolic risk factors, including obesity, diabetes, hypertension, and hypercholesterolemia in subjects with $\mathrm{CHD}$ and subjects without
CHD. Different logistic regression models with adjustments for potential confounders were performed to identify the association of each dependent variable and vitamin D status. First, the crude model with no adjustment was applied for each dependent variable. Various combinations of significant independent variables, including sociodemographic, lifestyle behaviors, sun exposure, the use of sunscreen, and the use of vitamin supplementation, were entered into the second model to predict the outcome variables. Furthermore, among the study participants, there were a few subjects who smoked a water-pipe and practiced vigorous exercise; hence, cigarette smoking and water-pipe smoking were combined for the logistic regression, and moderate and vigorous exercise was also combined. Moreover, overweight and obese subjects (defined as $25-29.9$ and $\geq 30 \mathrm{~kg} / \mathrm{m}^{2}$, respectively) were also combined in order to apply binary regression. The multivariate logistic regression results were reported including odds ratios (OR) with $95 \%$ confidence intervals (CI) for risk estimates. A $p$ value $<0.05$ was considered statistically significant.

Table 1: Socio-demographic, family history of CVD, and lifestyle behaviors variables according to vitamin $D$ status in subjects with $C H D$ and subjects without $C H D$. $P$-value based on $X^{2}$-test; *Saudi Riyal (1SR=0.37 AUD)

\begin{tabular}{|c|c|c|c|c|c|c|}
\hline \multirow[b]{2}{*}{ Variables } & \multicolumn{3}{|c|}{$\begin{array}{c}\text { Subjects with CHD } \\
N=130\end{array}$} & \multicolumn{3}{|c|}{$\begin{array}{l}\text { Subjects without CHD } \\
\qquad \mathrm{N}=195\end{array}$} \\
\hline & $\begin{array}{l}\text { Deficient } \\
(<20 \mathrm{ng} / \mathrm{ml}) \\
\% \text { (N) }\end{array}$ & $\begin{array}{l}\text { Adequate } \\
(\geq 20 \mathrm{ng} / \mathrm{ml}) \\
\% \text { (N) }\end{array}$ & P-value & $\begin{array}{c}\text { Deficient } \\
(<20 \mathrm{ng} / \mathrm{ml}) \\
\%(\mathrm{~N})\end{array}$ & $\begin{array}{c}\text { Adequate } \\
(\geq 20 \mathrm{ng} / \mathrm{ml}) \\
\%(\mathrm{~N})\end{array}$ & P-value \\
\hline $\begin{array}{l}\text { Age (years) } \\
<49 \\
\geq 49\end{array}$ & $\begin{array}{l}28.3(28) \\
71.7(71)\end{array}$ & $\begin{array}{c}16.1(5) \\
83.9(26)\end{array}$ & 0.175 & $\begin{array}{l}19.7(15) \\
80.3(61)\end{array}$ & $\begin{array}{l}37(44) \\
63(75)\end{array}$ & 0.011 \\
\hline $\begin{array}{l}\text { Gender } \\
\text { Male } \\
\text { Female }\end{array}$ & $\begin{array}{l}67.7(67) \\
32.3(32)\end{array}$ & $\begin{array}{l}48.4(15) \\
51.6(16)\end{array}$ & 0.052 & $\begin{array}{l}52.6(40) \\
47.4(36)\end{array}$ & $\begin{array}{l}69.7(83) \\
30.3(36)\end{array}$ & 0.016 \\
\hline $\begin{array}{l}\text { Marital status } \\
\text { Single } \\
\text { Married } \\
\text { Divorced }\end{array}$ & $\begin{array}{c}6.1(6) \\
72.2(72) \\
21.2(21)\end{array}$ & $\begin{array}{c}3.2(1) \\
61.3(19) \\
35.5(11)\end{array}$ & 0.253 & $\begin{array}{l}22.4(17) \\
63.2(48) \\
14.5(11)\end{array}$ & $\begin{array}{l}14.3(17) \\
77.3(92) \\
8.4(10)\end{array}$ & 0.099 \\
\hline $\begin{array}{l}\text { Citizenship } \\
\text { Saudis } \\
\text { Non-Saudis }\end{array}$ & $\begin{array}{l}81.8(81) \\
18.2(18)\end{array}$ & $\begin{array}{l}77.4(24) \\
22.6(7)\end{array}$ & .588 & $\begin{array}{l}77.6(59) \\
22.4(17)\end{array}$ & $\begin{array}{l}52.9(63) \\
47.1(56)\end{array}$ & 0.001 \\
\hline $\begin{array}{l}\text { Place of residence } \\
\text { Rural } \\
\text { Urban } \\
\text { Semi-rural }\end{array}$ & $\begin{array}{c}11.1(11) \\
85.9(85) \\
3(3)\end{array}$ & $\begin{array}{c}58.1(18) \\
38.7(12) \\
3.2(1)\end{array}$ & 0.433 & $\begin{array}{c}1.3(1) \\
97.4(74) \\
1.3(1)\end{array}$ & $\begin{array}{l}0.8(1) \\
99.2(118) \\
0(0)\end{array}$ & 0.431 \\
\hline $\begin{array}{l}\text { Education } \\
\text { Up to primary levels } \\
\text { High School and bachelor or diploma } \\
\text { Master or PhD }\end{array}$ & $\begin{array}{c}49.5(49) \\
49.5(49) \\
1(1)\end{array}$ & $\begin{array}{c}41.1(39) \\
48.8(105) \\
46.2(6)\end{array}$ & 0.489 & $\begin{array}{c}9.2(7) \\
82.9(63) \\
7.9(6)\end{array}$ & $\begin{array}{l}17.6(21) \\
78.2(93) \\
4.2(5)\end{array}$ & 0.169 \\
\hline $\begin{array}{l}\text { Employment } \\
\text { Employed (Full time, Part time, self-employed) } \\
\text { Unemployed (Student, Retired, House wife) }\end{array}$ & $\begin{array}{l}36.4(36) \\
63.6(63)\end{array}$ & $\begin{array}{l}19.4(6) \\
80.6(25)\end{array}$ & 0.007 & $\begin{array}{l}76.3(58) \\
23.7(18)\end{array}$ & $\begin{array}{l}84.9(101) \\
15.1(18)\end{array}$ & 0.133 \\
\hline $\begin{array}{l}\text { Family income (SR*/monthly) } \\
<5000 \\
5000-15000 \\
\geq 15000\end{array}$ & $\begin{array}{l}40.4(40) \\
41.4(41) \\
18.2(18)\end{array}$ & $\begin{array}{c}51.6(16) \\
29(9) \\
19.4(6)\end{array}$ & 0.439 & $\begin{array}{l}18.4(14) \\
66.4(52) \\
13.2(10)\end{array}$ & $\begin{array}{l}50.4(60) \\
35.3(42) \\
14.3(17)\end{array}$ & 0.001 \\
\hline $\begin{array}{l}\text { Smoking } \\
\text { Current smoker } \\
\text { Previous smoker } \\
\text { Non-smoker }\end{array}$ & $\begin{array}{l}20.2(20) \\
28.3(28) \\
51.5(51)\end{array}$ & $\begin{array}{c}9.7(3) \\
16.1(5) \\
74.2(23)\end{array}$ & 0.083 & $\begin{array}{c}27.6(21) \\
2.6(2) \\
69.7(53)\end{array}$ & $\begin{array}{c}15.1(18) \\
6.7(8) \\
78.2(93)\end{array}$ & 0.061 \\
\hline $\begin{array}{l}\text { Exercise } \\
\text { Never and rarely } \\
1-2 \text { times/week } \\
\text { More than 3-4 times/week }\end{array}$ & $\begin{array}{c}33.3(33) \\
17.2(17) 49.5(49)\end{array}$ & $\begin{array}{l}35.5(11) \\
16.1(5) \\
48.4(15)\end{array}$ & 0.974 & $\begin{array}{l}44.7(34) \\
26.3(20) \\
28.9(22)\end{array}$ & $\begin{array}{c}42(50) \\
21.8(26) \\
36.1(43)\end{array}$ & 0.551 \\
\hline $\begin{array}{l}\text { Family history of CVD } \\
\text { Yes } \\
\text { No }\end{array}$ & $\begin{array}{l}42.4(42) \\
57.6(57)\end{array}$ & $\begin{array}{l}35.5(11) \\
64.5(20)\end{array}$ & 0.493 & $\begin{array}{l}50(38) \\
50(38)\end{array}$ & $\begin{array}{l}36.1(43) \\
63.9(76)\end{array}$ & 0.055 \\
\hline
\end{tabular}




\section{Results}

Table 1 depicts the distribution of the socio-demographic characteristics, family history of CVD, and lifestyle behaviors variables of the study participants with and without CHD by vitamin D status. In the CHD patient, there was significant difference in employment status between the subjects with vitamin D deficiency and subjects with adequate vitamin D status. A significantly higher proportion of subjects in the vitamin D deficiency group were employed at the time of the survey compared with the subjects with adequate vitamin D status. In subjects without $\mathrm{CHD}$, there were significant differences in age, gender, citizenship, and family income between the subjects with vitamin D deficiency and subjects with adequate vitamin D status. A significantly higher proportion of subjects in the vitamin $\mathrm{D}$ deficiency group were older in age, male, Saudis, with low-medium family income compared with the subjects with adequate vitamin D status. Figure 2 shows the prevalence of cardio-metabolic risk factors among subjects with $\mathrm{CHD}$ and subjects without CHD. The prevalence of diabetes and obesity were significantly higher in subjects with $\mathrm{CHD}$ compared with subjects without CHD, $(35.4 \%$ and $14 \%, p \leq 0.001$, for diabetes, respectively, and $44 \%$ and $22 \%, p \leq 0.001$, for obesity, respectively). In contrast, the prevalence of high cholesterol levels and overweight were significantly higher in subjects without CHD compared with subjects with CHD ( $13.3 \%$ and $5.4 \%, p=0.02$, for high cholesterol levels, respectively, and $45 \%$ and $24.4 \%, p \leq 0.001$, for overweight, respectively). There was no significant difference in the prevalence of hypertension between the groups (Figure 2).

Table 2 depicts the results of multivariate logistic regression analyses for both subjects with $\mathrm{CHD}$ and subjects without CHD groups. In subjects without $\mathrm{CHD}$, there was no significant association observed between vitamin D deficiency and obesity, diabetes, hypertension, and hypercholesterolemia. In subjects with $\mathrm{CHD}$, vitamin $\mathrm{D}$ deficiency (serum $25(\mathrm{OH}) \mathrm{D}<20 \mathrm{ng} / \mathrm{mL}$ ) was significantly associated with an increased risk of diabetes $(p=0.04)$. After adjustment for age, gender, BMI, family history of CVD, vitamin D supplements, calcium supplements with vitamin $D$, sun exposure, and the use of sunscreen, the CHD patients with vitamin D deficiency (serum $25(\mathrm{OH}) \mathrm{D}<20 \mathrm{ng} / \mathrm{mL}$ ) were 2.9 times more likely to suffer from diabetes compared to those with adequate vitamin D levels (OR: $2.9,95 \%$ CI: 1.02-8.5, $p=0.04$ ). In subjects with $\mathrm{CHD}$, no significant associations were observed between vitamin D deficiency and other cardio-metabolic risk factors, including obesity, hypertension and hypercholesterolemia (Table 2).

\section{Discussion}

Several earlier studies have reported the relation of vitamin D status with various cardio-metabolic risk factors in different population groups [9,30,31]. However, there is an important unanswered question, which is whether the association between vitamin $\mathrm{D}$ deficiency and cardio-metabolic risk factors is partially due to their interrelationships with CHD? To move this field forward, there is a need for well-designed studies with an aim to systematically explore these associations. Therefore, the present study endeavored to compare the association of vitamin D status and cardio-metabolic risk factors in subjects with and without CHD. To our knowledge, this is the first study that revealed a differential association between vitamin $\mathrm{D}$ deficiency and cardiometabolic risk factors in Saudi adults with and without CHD.

Diabetes is a significant risk factor for developing CVD. Our results demonstrated that vitamin $\mathrm{D}$ deficiency, defined by using a cutoff of serum $25(\mathrm{OH}) \mathrm{D} \leq 20 \mathrm{ng} / \mathrm{mL}$ was significantly associated with increased risk of diabetes only in subjects with CHD. The association remained significant even after controlling for potential confounders. On the contrary, one case-control study in Saudi Arabia reported no association between vitamin D status and diabetes [24]. The authors concluded that vitamin D deficiency was highly prevalent in their study subjects regardless of the presence of diabetes. They further explained that due to not applying strict exclusion criteria, the subjects in the control group had medical conditions such as hypothyroidism and euthyroid multinodular goiter that affect vitamin D metabolism, and thereby led to high prevalence of vitamin $\mathrm{D}$ deficiency in the nondiabetic subjects [24]. However, in the Mini-Finland Health Survey,

Figure 2: Cardio-metabolic risk factors among subjects with CHD and subjects without CHD. HTN: Hypertension; DM: Diabetes; HC: Hypercholesterolemia.

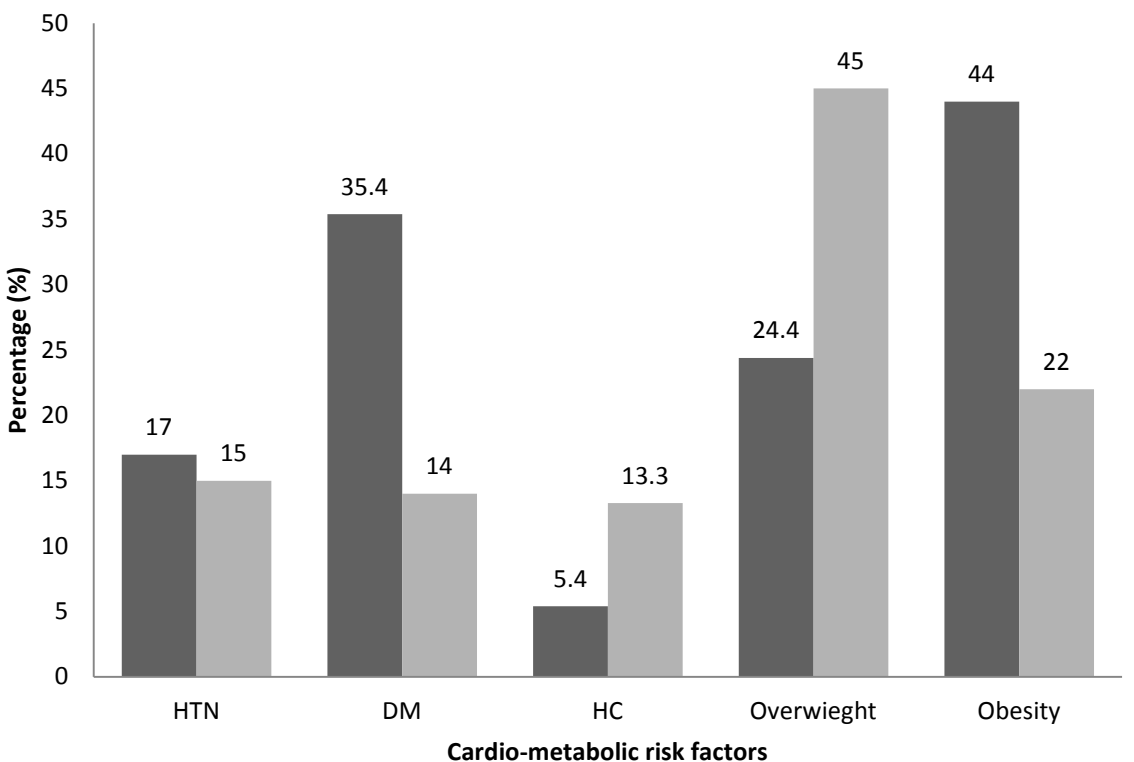

- Subjects with CHD $\quad$ Subjects without CHD 
Citation: Aljefree NM, Lee P, Saqqaf JMA, Ahmed F (2016) Association between Vitamin D Status and Cardio-Metabolic Risk Factors among Adults with and without Coronary Heart Disease in Saudi Arabia. J Diabetes Metab 7: 707. doi: 10.4172/2155-6156.1000707

Page 5 of 7

Table 2: Results of Multivariate Logistic Regression Analysis for subjects with CHD and subjects with-out CHD.

${ }^{1}$ Logistic Regression model with no adjustment

${ }^{2}$ Multivariate Logistic Regression model after adjustment for age, gender, smoking, exercise, vitamin D supplements, calcium supplements with vitamin D, sun exposure, and the use of sun screen.

${ }^{3}$ Multivariate Logistic Regression model after adjustment for age, gender, BMI, vitamin D supplements, calcium supplements with vitamin D, sun exposure, and the use of sun screen.

${ }^{4}$ Multivariate Logistic Regression model after adjustment for age, gender, BMI, vitamin D supplements, calcium supplements with vitamin D, sun exposure, and the use of sun screen.

${ }^{5}$ Multivariate Logistic Regression model after adjustment for age, gender, BMI, family history of CVD, vitamin D supplements, calcium supplements with vitamin D, sun exposure, and the use of sun screen.

${ }^{6}$ Multivariate Logistic Regression model after adjustment for age, gender, citizenship, vitamin D supplements, calcium supplements with vitamin D, sun exposure, and the use of sun screen

${ }^{7}$ Multivariate Logistic Regression model after adjustment for age, gender, BMI, vitamin D supplements, calcium supplements with vitamin D, sun exposure, and the use of sun screen.

${ }^{8}$ Multivariate Logistic Regression model after adjustment for age, gender, BMI, exercise, family history of CVD, vitamin D supplements, calcium supplements with vitamin $\mathrm{D}$, sun exposure, and the use of sun screen.

${ }_{9}$ Multivariate Logistic Regression model after adjustment for age, gender, BMI, education, smoking, vitamin D supplements, calcium supplements with vitamin D, sun exposure, and the use of sun screen.

$* 0.05$

\begin{tabular}{|c|c|c|c|c|}
\hline \multirow[t]{2}{*}{ Variables } & \multicolumn{2}{|c|}{$\begin{array}{l}\text { Subjects with CHD } \\
N=130\end{array}$} & \multicolumn{2}{|c|}{$\begin{array}{l}\text { Subjects without CHD } \\
\qquad N=195\end{array}$} \\
\hline & Crude OR (95\% CI) & Adjusted OR $(95 \% \mathrm{Cl})$ & Crude OR $(95 \% \mathrm{Cl})$ & Adjusted OR $(95 \% \mathrm{Cl})$ \\
\hline $\begin{array}{c}\text { Obesity } \\
\text { Adequate }(\geq 20 \mathrm{ng} / \mathrm{ml}) \\
\text { Deficient }(<20 \mathrm{ng} / \mathrm{ml})\end{array}$ & $\begin{array}{c}1.0 \text { (referent) } \\
(1.6,0.6-3.7)^{1}\end{array}$ & $\begin{array}{c}1.0 \text { (referent) } \\
(2,0.7-6)^{2}\end{array}$ & $\begin{array}{c}1.0 \text { (referent) } \\
(1.3,0.7-2.4)^{1}\end{array}$ & $\begin{array}{c}1.0 \text { (referent) } \\
(1.9,0.9-3.8)^{6}\end{array}$ \\
\hline $\begin{array}{c}\text { Diabetes } \\
\text { Adequate }(\geq 20 \mathrm{ng} / \mathrm{ml}) \\
\text { Deficient }(<20 \mathrm{ng} / \mathrm{ml})\end{array}$ & $\begin{array}{c}1.0 \text { (referent) } \\
(0.4,0.17-1.1)^{1}\end{array}$ & $\begin{array}{c}1.0 \text { (referent) } \\
(2.9,1.02-8.5)^{3 *}\end{array}$ & $\begin{array}{c}1.0 \text { (referent) } \\
(1.3,0.5-2.9)^{1}\end{array}$ & $\begin{array}{c}1.0 \text { (referent) } \\
(1.4,0.5-3.8)^{7}\end{array}$ \\
\hline $\begin{array}{c}\text { Hypertension } \\
\text { Adequate }(\geq 20 \mathrm{ng} / \mathrm{ml}) \\
\text { Deficient }(<20 \mathrm{ng} / \mathrm{ml})\end{array}$ & $\begin{array}{c}1.0 \text { (referent) } \\
(0.8,0.2-2.2)^{1}\end{array}$ & $\begin{array}{c}1.0 \text { (referent) } \\
(0.7,0.2-2.2)^{4}\end{array}$ & $\begin{array}{c}1.0 \text { (referent) } \\
(0.79,0.3-1.8)^{1}\end{array}$ & $\begin{array}{c}1.0 \text { (referent) } \\
(0.6,0.2-1.8)^{8}\end{array}$ \\
\hline $\begin{array}{l}\text { Hypercholesterolemia } \\
\text { Adequate }(\geq 20 \mathrm{ng} / \mathrm{ml}) \\
\text { Deficient }(<20 \mathrm{ng} / \mathrm{ml})\end{array}$ & $\begin{array}{c}1.0 \text { (referent) } \\
(0.77,0.14-4.1)^{1}\end{array}$ & $\begin{array}{c}1.0 \text { (referent) } \\
(0.8,0.04-1.6)^{5}\end{array}$ & $\begin{array}{c}1.0 \text { (referent) } \\
(1.1,0.5-2.7)^{1}\end{array}$ & $\begin{array}{c}1.0 \text { (referent) } \\
(0.6,0.2-2.3)^{9}\end{array}$ \\
\hline
\end{tabular}

a significant inverse association between serum vitamin $\mathrm{D}$ level and the incidence of diabetes was found after a 17-year follow-up [32]. Several other studies also reported similar results [9,33]. Furthermore, a number of studies reported an association between vitamin D deficiency and impaired glucose metabolism. For example, in a study of healthy, non-diabetic postmenopausal females, vitamin $\mathrm{D}$ deficiency $(<12.5 \mathrm{ng} / \mathrm{mL})$ was associated with fasting serum glucose [34]. The possible mechanism for the effect of vitamin $\mathrm{D}$ deficiency on diabetes is not fully understood; however, previous studies suggested that vitamin D deficiency may contribute to insulin resistance. Low levels of serum vitamin $\mathrm{D}$ may also contribute to insulin secretion through its direct effect on the $\beta$-cell function [35]. Moreover, vitamin D deficiency could be an indirect risk factor for $\mathrm{CHD}$ as it may produce serious consequences such as immunosuppressive effect and inflammatory markers [36].

On the other hand, we did not find any association between diabetes and vitamin $\mathrm{D}$ deficiency among subjects without $\mathrm{CHD}$. One of the possible explanations for this finding is that vitamin D deficiency might influence the $\beta$-cell functions or exacerbate insulin resistance in diabetic subjects only among those with CHD. However, with the current data set we are unable to confirm this postulation. Another possible reason for these findings could be due to the higher prevalence and severity of vitamin $\mathrm{D}$ deficiency (serum $25(\mathrm{OH}) \mathrm{D}<20 \mathrm{ng} / \mathrm{mL}$ ) among subjects with CHD (76.2\%) than subjects without CHD (39\%). Further, the prevalence of severe vitamin D deficiency (serum $25(\mathrm{OH})$ $\mathrm{D}<10 \mathrm{ng} / \mathrm{mL}$ ) was also more common in subjects with CHD (46.2\%) compared to the subjects without CHD (3.1\%) (Data not showed).

Obesity is one of the well-established risk factors for CVD and it is considered a significant health problem in both developed and developing nations. Numerous studies have indicated that low levels of serum vitamin D were inversely associated with different assessing indicators of obesity, including BMI, body weight, and waist circumference (WC). In the United States, the NHANES (1988-1994) reported a significant association between obesity and lower serum levels of vitamin D [33]. Similar results have been reported in other developed countries $[30,37,38]$. The availability of vitamin $\mathrm{D}$ from both sources, sun exposure and dietary intake, is reduced in obese subjects because of confinement in adipose tissues, which provide the possible explanation for the relationship between vitamin D deficiency and obesity [39]. In Saudi Arabia, one study has examined the association between vitamin $\mathrm{D}$ status and obesity among both adolescent and adults [25]. However, they reported an association between vitamin D deficiency and obesity in adolescents but not adults [25]. The current research findings showed no association between high BMI and serum vitamin D levels among subjects with and without CHD. In the present study, BMI was used as an indicator of obesity, which is not an ideal tool to measure body fat; thus, further studies are needed to examine the association between vitamin $\mathrm{D}$ status and obesity using more appropriate indicators, such as total body fat $(\mathrm{TBF})$, waist-to-hip ratio (WHR), and WC [40].

The present study also showed no significant association between vitamin $\mathrm{D}$ deficiency and hypertension in both groups, and a similar finding was reported for the Dutch population [41]. On the other hand, other studies found an inverse association between vitamin $\mathrm{D}$ status and hypertension [9,31,33]. However, a recently published meta-analysis has shown no significant effect of vitamin D supplementation on SBP and DBP [42]. Furthermore, results of this study showed no significant association between vitamin $\mathrm{D}$ deficiency and hypercholesterolemia in both groups, which is consistent with previous research [43]. It was noticed that few studies worldwide have focused on the association between vitamin D status and blood lipids in general, especially high cholesterol levels, even though 
Citation: Aljefree NM, Lee P, Saqqaf JMA, Ahmed F (2016) Association between Vitamin D Status and Cardio-Metabolic Risk Factors among Adults with and without Coronary Heart Disease in Saudi Arabia. J Diabetes Metab 7: 707. doi: 10.4172/2155-6156.1000707

Page 6 of 7

they are the major risk factors for CHD [44]. Some studies reported significant association between low serum vitamin D levels and high triglycerides $[33,45,46]$, but not with hypercholesterolemia. The possible explanation for our results is that all subjects in the current study were hospital-based patients; thus, if they have been clinically diagnosed with hypertension and hypercholesterolemia, they would be on medication for those conditions. Hence, the prevalence of hypertension and hypercholesterolemia in our sample is lower than the actual prevalence, thus could not detect any associations of vitamin D status with hypertension and hypercholesterolemia. In Saudi Arabia and the Gulf region, no previous studies have examined the association of vitamin D deficiency with hypertension and hypercholesterolemia.

A few randomized controlled trials (RCTs) have evaluated the effect of vitamin D supplementation on the reduction of cardio-metabolic risk. They reported no significant difference in glucose metabolism [47], hypertension levels [48], and/or weight loss between vitamin D supplementation groups and control groups [46].

This study has a number of limitations. The research design is one limitation, as it cannot deduce the cause-effect relationship. Recall bias could be another limitation because study participants were asked to remember some information, including their smoking history. In addition, a single measurement of serum vitamin D levels was considered a limitation since multiple measurements reflect the average vitamin D status. The present study also has a number of strengths. The measurements of cardio-metabolic risk factors were done in the same hospitals and were not self-reported, which increased internal validity. In addition, adjusting for a varied range of socio-demographic and behavioral confounding factors, such as using vitamin D supplements, level of sun exposure, and the use of sunscreen, to demonstrate the association between low vitamin D serum levels and cardio-metabolic risk factors increased the validity of the study results.

\section{Conclusion}

In conclusion, the current study revealed that risk of diabetes was independently associated with vitamin D deficiency only among subjects with $\mathrm{CHD}$ and not subjects without CHD. Furthermore, no significant associations were detected between vitamin $\mathrm{D}$ deficiency and other cardio-metabolic risk factors, including obesity, hypertension, and hypercholesterolemia, in both groups. Further studies with larger sample sizes are needed to confirm these results.

\section{Acknowledgment}

The authors wish to thank Tunsi private hospital, King Abdul-Aziz University hospital academic affairs center and KAMC research center for their assistance in data collection. Najlaa Aljefree is supported by a scholarship from King Abdul Aziz University for Nutrition and Dietetics. The King Abdul Aziz University had no role in the design, analysis, or writing of this paper. The authors declare that they have no competing interests.

\section{Author Contribution}

NA, contributed to the design of the study, collected and analyzed the data and took a lead role in developing the manuscript; JA, assist in conducting research and data collection; $\mathrm{PL}$, provided guidance in performing statistical analysis and contributed to the design of the study; FA, provided guidance on the overal research plan and design of the study, and contributed to the data analysis plan, interpretation of results, and critical revision of the manuscript. All authors have read and approved the final manuscript.

\section{References}

1. Holick MF (2007) Vitamin D deficiency. N Engl J Med 357: 266-281.

2. Looker AC, Dawson-Hughes B, Calvo MS, Gunter EW, Sahyoun NR (2002) Serum 25-hydroxyvitamin D status of adolescents and adults in two seasonal subpopulations from NHANES III. Bone 30: 771-777.
3. van der Wielen RP, Löwik MR, van den Berg $\mathrm{H}$, de Groot LC, Haller J, et al. (1995) Serum vitamin $D$ concentrations among elderly people in Europe. Lancet 346: 207-210.

4. Bettica P, Bevilacqua M, Vago T, Norbiato G (1999) High prevalence of hypovitaminosis $D$ among free-living postmenopausal women referred to an osteoporosis outpatient clinic in northern Italy for initial screening. Osteoporosis Int 9: 226-229.

5. Mithal A, Wahl DA, Bonjour JP, Burckhardt P, Dawson-Hughes B, et al. (2009) Global vitamin D status and determinants of hypovitaminosis D. Osteoporos Int 20: 1807-1820.

6. Kim DH, Sabour S, Sagar UN, Adams S, Whellan DJ (2008) Prevalence of hypovitaminosis $D$ in cardiovascular diseases (from the National Health and Nutrition Examination Survey 2001 to 2004). Am J Cardiol 102: 1540-1544.

7. Kendrick J, Targher G, Smits G, Chonchol M (2009) 25-Hydroxyvitamin D deficiency is independently associated with cardiovascular disease in the Third National Health and Nutrition Examination Survey. Atherosclerosis 205: 255-260.

8. Lee JH, Gadi R, Spertus JA, Tang F, O'Keefe JH (2011) Prevalence of vitamin $\mathrm{D}$ deficiency in patients with acute myocardial infarction. Am J Cardiol 107: 1636-1638.

9. Anderson JL, May HT, Horne BD, Bair TL, Hall NL, et al. (2010) Relation of vitamin $\mathrm{D}$ deficiency to cardiovascular risk factors, disease status, and incident events in a general healthcare population. Am J Cardiol 106: 963-968.

10. Nitta K (2011) Impact of Vitamin D Metabolism on Cardiovascular Disease. Int J Clin Med 2.

11. Nemerovski CW, Dorsch MP, Simpson RU, Bone HG, Aaronson KD, et al. (2009) Vitamin D and cardiovascular disease. Pharmacotherapy 29: 691-708.

12. Aljefree N, Ahmed F (2015) Prevalence of Cardiovascular Disease and Associated Risk Factors among Adult Population in the Gulf Region: A Systematic Review. Adv Public Health 21: 23-36.

13. Al-Nozha MM, Abdullah M, Arafah MR, Khalil MZ, Khan NB, et al. (2007) Hypertension in Saudi Arabia. Saudi Med J 28: 77-84.

14. Al-Nozha MM, Al-Maatouq MA, Al-Mazrou YY, Al-Harthi SS, Arafah MR, et al. (2004) Diabetes mellitus in Saudi Arabia. Saudi Med J 25: 1603-1610.

15. Al-Nozha MM, Al-Mazrou YY, Al-Maatouq MA, Arafah MR, Khalil MZ, et al (2005) Obesity in Saudi Arabia. Saudi Med J 26: 824-829.

16. Al-Nozha MM, Arafah MR, Al-Maatouq MA, Khalil MZ, Khan NB, et al. (2008) Hyperlipidemia in Saudi Arabia. Saudi Med J 29: 282-287.

17. Al-Nuaim AA, Bamgboye EA, al-Rubeaan KA, al-Mazrou Y (1997) Overweight and obesity in Saudi Arabian adult population, role of socio-demographic variables. J Comm Health 22: 211-223.

18. Whiting DR, Guariguata L, Weil C, Shaw J (2011) IDF diabetes atlas: globa estimates of the prevalence of diabetes for 2011 and 2030. Diabetes Res Clin Pract 94: 311-321.

19. Al-Nozha MM, Arafah MR, Al-Mazrou YY, Al-Maatouq MA, Khan NB, et al (2004) Coronary artery disease in Saudi Arabia. Saudi Med J 25: 1165-1171.

20. Kumosani TA, Alama MN, lyer A (2007) Cardiovascular diseases in Saudi Arabia. In Press 21: 23-29.

21. Aljefree N, Lee P, Alsaqqaf J, Alattas K, Ahmed F (2016) Association between vitamin D status and coronary heart disease among adults in Saudi Arabian: a case-control study. Healthcare 4:77

22. Fields J, Trivedi NJ, Horton E, Mechanick JI (2011) Vitamin D in the Persian Gulf: integrative physiology and socioeconomic factors. Curr Osteoporos Rep 9: 243-250.

23. Aljefree N, Ahmed $\mathrm{F}$ (2015) Association between dietary pattern and risk of cardiovascular disease among adults in the Middle East and North Africa region: A systematic review. Food Nutr Res 59.

24. Alhumaidi M, Agha A, Dewish M (2013) Vitamin d deficiency in patients with type-2 diabetes mellitus in southern region of saudi arabia. Maedica (Buchar) 8: 231-236.

25. Al-Daghri NM, Al-Saleh Y, Aljohani N, Alokail M, Al-Attas O, et al. (2015) Vitamin D Deficiency and Cardiometabolic Risks: A Juxtaposition of Arab Adolescents and Adults. PLoS One 10: e0131315. 
Citation: Aljefree NM, Lee P, Saqqaf JMA, Ahmed F (2016) Association between Vitamin D Status and Cardio-Metabolic Risk Factors among Adults with and without Coronary Heart Disease in Saudi Arabia. J Diabetes Metab 7: 707. doi: 10.4172/2155-6156.1000707

26. Wells S, Broad J, Jackson R (2004) Alcohol consumption and its contribution to the burden of coronary heart disease in middle-aged and older New Zealanders: a population-based case-control study. NZMJ 117

27. Shaikh RB, Vijayaraghavan N, Sulaiman AS, Kazi S, Shafi MS (2008) The acute effects of Waterpipe smoking on the cardiovascular and respiratory systems. J Prev Med Hyg 49: 101-107.

28. Shils ME, Shike M (2006) Modern nutrition in health and disease. Lippincott Williams \& Wilkins 21: 22-36.

29. Gallagher JC, Sai AJ (2010) Vitamin D insufficiency, deficiency, and bone health. J Clin Endocrinol Metab 95: 2630-2633.

30. Hintzpeter B, Mensink GB, Thierfelder W, Müller MJ, Scheidt-Nave C (2008) Vitamin D status and health correlates among German adults. Eur J Clin Nutr 62: $1079-1089$

31. Forman JP, Giovannucci E, Holmes MD, Bischoff-Ferrari HA, Tworoger SS, et al. (2007) Plasma 25-hydroxyvitamin D levels and risk of incident hypertension. Hypertension 49: 1063-1069.

32. Mattila C, Knekt P, Männistö S, Rissanen H, Laaksonen MA, et al. (2007) Serum 25-hydroxyvitamin $D$ concentration and subsequent risk of type 2 diabetes. Diabetes Care 30: 2569-2570.

33. Martins D, Wolf M, Pan D, Zadshir A, Tareen N, et al. (2007) Prevalence of cardiovascular risk factors and the serum levels of 25-hydroxyvitamin $D$ in the United States: data from the Third National Health and Nutrition Examination Survey. Arch Intern Med 167: 1159-1165

34. Need AG, O'Loughlin PD, Horowitz M, Nordin BE (2005) Relationship between fasting serum glucose, age, body mass index and serum 25 hydroxyvitamin $D$ in postmenopausal women. Clin Endocrinol (Oxf) 62: 738-741.

35. Dalgård C, Petersen MS, Weihe $P$, Grandjean $P$ (2011) Vitamin D status in relation to glucose metabolism and type 2 diabetes in septuagenarians. Diabetes Care 34: 1284-1288.

36. Papandreou D, Hamid ZT (2015) The Role of Vitamin D in Diabetes and Cardiovascular Disease: An Updated Review of the Literature. Dis Markers 25: 580474.

37. Konradsen S, Ag H, Lindberg F, Hexeberg S, Jorde R (2008) Serum 1,25-dihydroxy vitamin $\mathrm{D}$ is inversely associated with body mass index. Eur $\mathrm{J}$ Nutr 47: 87-91.

38. Macdonald HM, Mavroeidi A, Barr RJ, Black AJ, Fraser WD, et al. (2008) Vitamin D status in postmenopausal women living at higher latitudes in the UK in relation to bone health, overweight, sunlight exposure and dietary vitamin D. Bone 42: 996-1003.

39. Baz-Hecht M, Goldfine AB (2010) The impact of vitamin D deficiency on diabetes and cardiovascular risk. Curr Opin Endocrinol Diabetes Obes 17 113-119.

40. Burkhauser RV, Cawley J (2008) Beyond BMI: the value of more accurate measures of fatness and obesity in social science research. J Health Econ 27: 519-529.

41. Snijder MB, Lips P, Seidell JC, Visser M, Deeg DJ, et al. (2007) Vitamin D status and parathyroid hormone levels in relation to blood pressure: a populationbased study in older men and women. J Intern Med 261: 558-565.

42. Pittas AG, Chung M, Trikalinos T, Mitri J, Brendel M, et al. (2010) Systematic review: Vitamin $D$ and cardiometabolic outcomes. Ann Intern Med 152: 307-314.

43. Forrest KY, Stuhldreher WL (2011) Prevalence and correlates of vitamin D deficiency in US adults. Nutr Res 31: 48-54.

44. Jorde R, Figenschau Y, Hutchinson M, Emaus N, Grimnes G (2010) High serum 25-hydroxyvitamin $D$ concentrations are associated with a favorable serum lipid profile. Eur J Clin Nutr 64: 1457-1464.

45. Muldowney S, Lucey AJ, Paschos G, Martinez JA, Bandarra N, et al. (2011) Relationships between vitamin $\mathrm{D}$ status and cardio-metabolic risk factors in young European adults. Ann Nutr Metab 58: 85-93.

46. Zittermann A, Frisch S, Berthold HK, Götting C, Kuhn J, et al. (2009) Vitamin D supplementation enhances the beneficial effects of weight loss on cardiovascular disease risk markers. Am J Clin Nutr 89: 1321-1327.

47. Jorde R, Figenschau Y (2009) Supplementation with cholecalciferol does not improve glycaemic control in diabetic subjects with normal serum 25-hydroxyvitamin D levels. Eur J Nutr 48: 349-354.

48. Margolis KL, Ray RM, Van Horn L, Manson JE, Allison MA, et al. (2008) Effect of calcium and vitamin D supplementation on blood pressure: the Women's Health Initiative Randomized Trial. Hypertension 52: 847-855.
Citation: Aljefree NM, Lee P, Saqqaf JMA, Ahmed F (2016) Association between Vitamin D Status and Cardio-Metabolic Risk Factors among Adults with and without Coronary Heart Disease in Saudi Arabia. J Diabetes Metab 7 : 707. doi: 10.4172/2155-6156.1000707
OMICS International: Open Access Publication Benefits \& Features

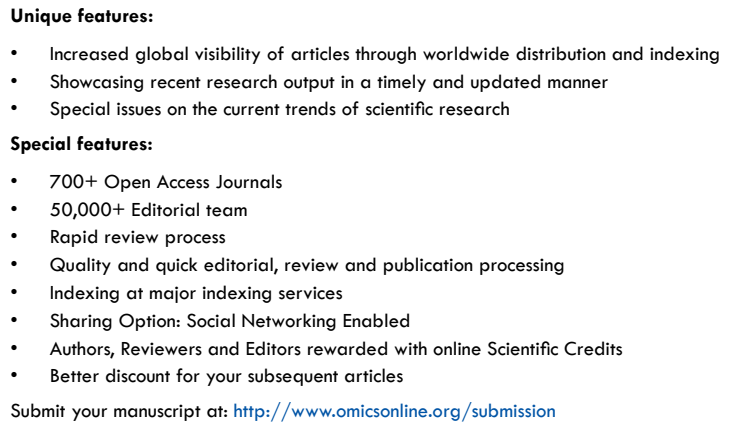

